\title{
Creating a GIS database for nursing home evacuation planning in Virginia Beach, Virginia
}

\author{
Randall S. Dawson \\ West Virginia University
}

Follow this and additional works at: https://researchrepository.wvu.edu/etd

\section{Recommended Citation}

Dawson, Randall S., "Creating a GIS database for nursing home evacuation planning in Virginia Beach, Virginia" (2007). Graduate Theses, Dissertations, and Problem Reports. 1851.

https://researchrepository.wvu.edu/etd/1851

This Thesis is protected by copyright and/or related rights. It has been brought to you by the The Research Repository @ WVU with permission from the rights-holder(s). You are free to use this Thesis in any way that is permitted by the copyright and related rights legislation that applies to your use. For other uses you must obtain permission from the rights-holder(s) directly, unless additional rights are indicated by a Creative Commons license in the record and/ or on the work itself. This Thesis has been accepted for inclusion in WVU Graduate Theses, Dissertations, and Problem Reports collection by an authorized administrator of The Research Repository @ WVU. For more information, please contact researchrepository@mail.wvu.edu. 


\title{
Creating a GIS Database for Nursing Home Evacuation Planning in Virginia Beach, Virginia.
}

\author{
Randall S. Dawson
}

\author{
Project report submitted to the \\ Eberly College of Arts and Sciences \\ at West Virginia University \\ in partial fulfillment of the requirements \\ for the degree of
Master of Arts
in
Geography
Gregory Elmes, Ph.D., Chair
Kenneth Martis, Ph.D.
Amy Hessl, Ph.D. \\ Department of Geology and Geography
}

Morgantown, West Virginia

2007

Copyright 2007, Randall S. Dawson 


\section{Abstract \\ Creating a GIS Database for Nursing Home Evacuation Planning in Virginia Beach, Virginia.}

\section{Randall S. Dawson}

The focus of this project is planning for the evacuation of the nursing homes of the city of Virginia Beach, VA in response to a hurricane risk. The population of nursing homes, hospitals and assisted living communities need special assistance when evacuating an area, requiring medications, equipment, and specialized transportation. Previous studies for Virginia Beach have provided generalizations for the population as a whole yet have provided very little data for specific communities such as nursing homes. A GIS database is created for nursing home establishments including road networks, bridges and tunnels, elevation, estimated facility population, and recently modeled storm surge data. This study shows that some nursing home evacuation plans are inadequate for predicted hurricanes of category three and above and need to be readdressed. The research identifies and provides maps and other geographic information essential for contingency planning. 


\section{Acknowledgements}

I would like to thank all of my colleagues - faculty, staff, and students - at the WVU Department of Geology and Geography for their continuous dedication in helping me grown as an academic, professional, and a person. They provided me with an outstanding atmosphere, both in the classroom and in day to day conversations. The people I have been surrounded by have helped me grow as a researcher, and ultimately, as a geographer. I would like to thank Dr. Kenneth Martis and Dr. Amy Hessl for their encouragement and guidance while reviewing this work and for serving on my thesis committee and I would especially like to thank Dr. Gregory Elmes for his patience, expertise, and enduring support throughout this research. No matter how far I strayed from the point of my thesis or the vast number of wrong roads I traveled down during my research, Dr. Elmes was always there to bring me back to my focus point. My appreciation goes out to the administrators of nursing homes and emergency service offices of Virginia Beach, taking the time out of their busy days while assisting an aspiring graduate student. And finally, I would like to thank the love of my life, Mary Kelly, for gracefully putting up with my frantic moments, long nights, and many traveling days away from home during this adventure of research and writing. It was through her support that I was able to accomplish this important goal in my life. 


\section{Table of Contents}

Abstract

Acknowledgements

Table of Figures $\quad$ v

Table of Tables $\quad$ vi

Section 1: Introduction and Project Background 1

Section 2: Goals and Objectives $\quad 4$

Section 3: Research Questions $\quad 5$

$\begin{array}{lr}\text { Section 4: Methods } & 8\end{array}$

$\begin{array}{lr}\text { Section 5: Results and Findings } & 13\end{array}$

$\begin{array}{lr}\text { Section 6: Conclusions } & 27\end{array}$

List of References

Annex A - Interviews $\quad 33$ 
Table of Figures

Figure 1: Photo of St. Rita's Nursing Home post Katrina 2

Figure 2: Coastline of Virginia Beach 4

Figure 3: Hurricane Tracking 1980-2005 7

Figure 4: Homes and Shelters during Category Three Surge 14

Figure 5: Possible Category Three Flooding for Nursing Homes 15

Figure 6: Category Four Storm Surge 17

Figure 7: Berger-Goodrich/Oakwood Nursing Homes, Category Three Surge 18

Figure 8: Heritage Hall/Bayside Nursing Homes Category, Three Surge 19

Figure 9: River Point/Beacon Shores/Sentara Nursing Homes, Category Three Surge $\quad \mathbf{2 0}$

Figure 10: Westminster-Canterbury Nursing Homes, Category Three Surge 22

Figure 11: Seaside Nursing Homes, Category Three Surge 23

Figure 12: Berger-Goodrich/Oakwood Nursing Homes, Category Four Surge 24

Figure 13: Heritage Hall/Bayside Nursing Homes, Category Four Surge 25

Figure 14: Bay Point/Virginia Beach Health/Windermere Nursing Homes, Category Four Surge 
Table of Tables

Table 1: Saffir-Simpson Scale

Table 2: GIS Data Layers 


\section{Section 1: Introduction and Project Background}

Hurricanes like Katrina in 2005 provide an object lesson with regard to the special attention to the aid necessary for the sick and elderly in the most extreme of conditions. Whether the consequences are fatalities following direct destruction of built environments or are due to the hardships that follow, the lack of hurricane preparedness of nursing homes and similar facilities remains a significant problem. This project takes a geographic information management approach, vital in developing a community's capabilities and expertise to respond to a catastrophic disaster. Following Hurricane Katrina, New Orleans and parts of Mississippi, in conjunction with the federal government, conducted brainstorming sessions discussing successes and failures for future help in the evacuation of hospital patients and nursing home residents; claiming it a top priority (Walker 2006). This project attempts to learn from the Katrina experience in order to identify the geographic information necessary to upgrade emergency action plans in Virginia Beach. After introducing the background events, the project goals and objectives are established in the second section. The third section specifies the research questions and the methods are detailed in section four. Results and findings are set out in section five, and the conclusions are found in the final section.

The decision not to evacuate during Hurricane Katrina proved to be fatal for some nursing home patients in Louisiana. Of the fatalities, 74\% were among people aged 60 and over and nearly $20 \%$ of the fatalities were recovered from nursing homes (Terwilliger 2007). These statistics raise legal issues about who is responsible for making the decision to shelter in place or evacuate the region. In one incident, after the deaths of 34 patients in Rita's Nursing Home located in St. Bernard Parish, the landlords have filed civil lawsuits against government entities such as Governor Kathleen Blanco 
and the Army Corps of Engineers listing them as co-defendants. This third-party demand could result in a decision that other defendants are liable for the deaths, either in whole or in part, and will be held liable in the future (Roberts 2006).

\section{Figure 1: St. Rita's Nursing Home Post Hurricane Katrina, 2005}

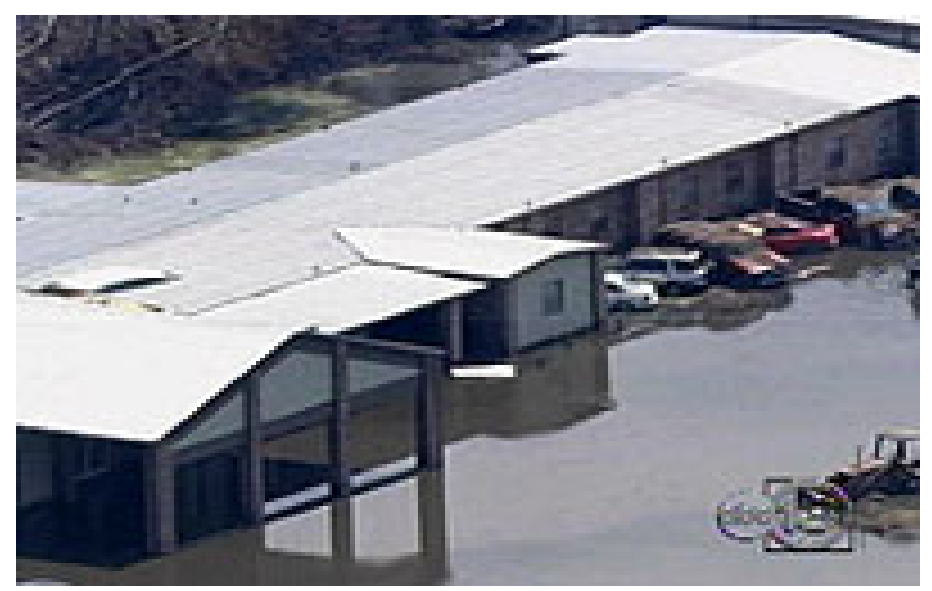

(Source:http://images.search.yahoo.com/search/images?_adv_prop=image\&va=st + rita $\% 27 \mathrm{~s}+$ nursing + home $\& s z=a l l \& e i=U T F-8 \& f r=y f p-t-501 \& b=21$, July 14,2007 )

More than 30 civil lawsuits are filed against the owners of Rita's Nursing Home and, in the fall of 2005, Louisiana's attorney general indicted them for negligent homicide. The owners, who ran the nursing home for 20 years, believed that they could safely take care of their patients at the facility without risking a difficult evacuation that could injure their frail, elderly patients (Roberts 2006). University of South Carolina researchers studied a mix of rural and urban nursing homes that sheltered Katrina nursing home evacuees in Mississippi, during which they discussed administrators' and staff experiences during and after the disaster (Laditka 2006). This research could set a precedent for how nursing homes may be found liable and accountable for their patients; even under the most extreme conditions.

In February 16, 2006, the United States Government Accountability Office submitted a report to Congressional Committees titled "Disaster Preparedness: Preliminary 
Observations on the Evacuation of Hospitals and Nursing Homes Due to Hurricanes."

This report found that, although state and local governments might issue evacuation orders, most hospital and nursing homes are exempt from these orders and prefer to shelter in place, except in extreme conditions. The directors or administrators consider the availability of adequate resources to shelter in place, the risks to patients in deciding when to evacuate, the availability of transportation to move patients and of receiving facilities to accept patients, and the destruction of the facility's or community's infrastructure while making the decision to evacuate (United States Government Accounting Office 2006). The National Disaster Medical System (NDMS), a federal system, was established to provide assistance with evacuation of hospital patients by providing transportation from the evacuation area to safety, but federal officials confirmed the NDMS was not set up nor is it currently configured to provide assistance evacuating nursing homes and the DOD, HHS, DHS, and VA officials all generally agreed with them (United States Government Accounting Office 2006). Understanding this omission, FEMA has placed nursing homes in a Special Needs category of and is working hard to understand and plan for this vulnerable segment of our population. They support and strongly urge each nursing facility to develop an Individualized Emergency Action Plan (IEAP).

Hurricane Katrina and the studies that followed inspired me to conduct similar research on nursing homes in Virginia Beach. My intention is to assist the various homes by providing an up-to-date Geographic Information System (GIS) tool to utilize while making the decision to shelter in place or evacuate prior to hurricane landfall. While the project draws on the areas of Physical, Environmental Hazards, and Human Geography, 
the primary focus of this research is Applied Geography, especially with respect to Geographic Information Science.

\section{Section 2: Goals and Objectives}

The objective of this project is to investigate the plans and procedures for the evacuation of nursing homes located in Virginia Beach, VA in the event of a hurricane. My goals are to produce a needs assessment of the geographic information and to implement a database necessary to affect a safe and efficient evacuation plan for the nursing homes.

To achieve

Figure 2: Coastline of Virginia Beach

the objective and

goals, I reviewed the relevant dynamics

of hurricanes, gathered data on past hurricanes that are applicable to Virginia Beach,

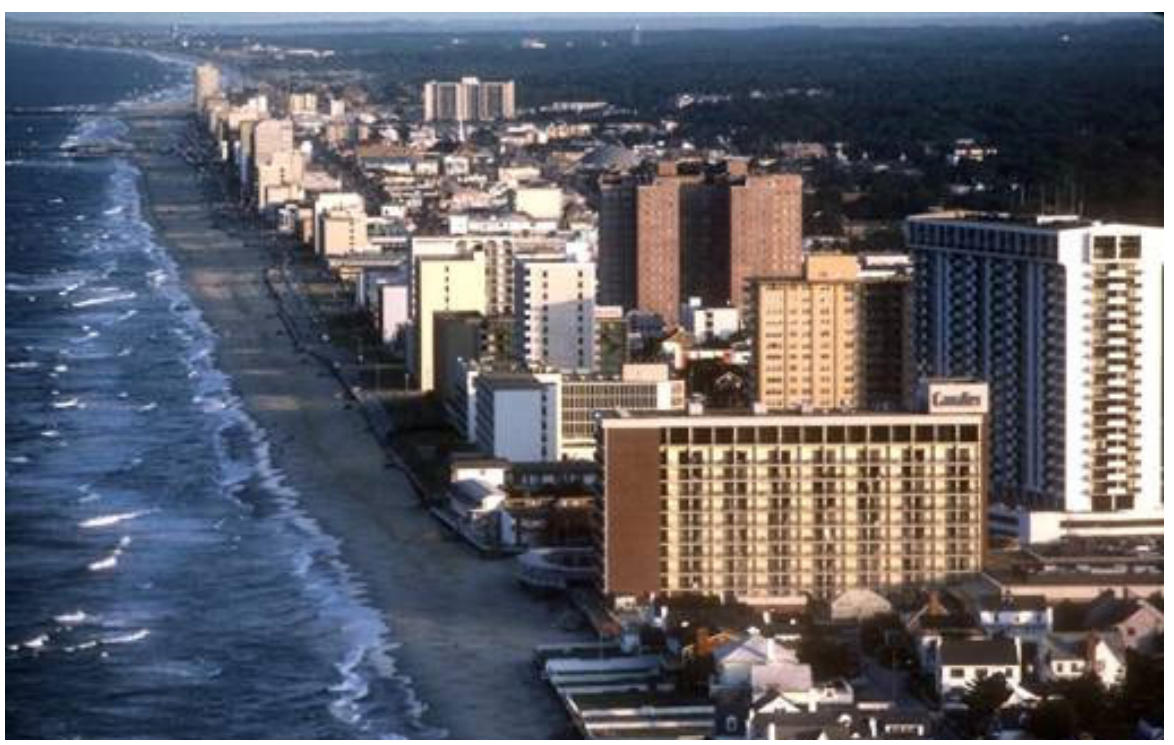

Source: http://www.nccrealtorinc.com/files/410781/virginia_beach.jpg examined

pertinent federal codes and local planning regulations, and surveyed various emergency service offices to understand what assistance is available for nursing homes in the Virginia Beach area. A GIS database was built in ArcGIS тм to aid emergency planners in the evaluation of each nursing home's emergency action plan.

This project considered 13 nursing homes and evaluated their decision to shelter in place in relation to recent storm surge data for the area, elevation, and relative location 
to shelters; thereby building a series of situations for the Department of Public Health of Virginia Beach to assist the city in emergency planning for this type of critical facility. Further data was collected on the nursing facilities' population (patients and staff), Medivac needs, transportation plans, generator status, and food and water supplies.

While it is impossible to pinpoint all the variables contributing to the efficient evacuation of an area, the Virginia Beach area is an ideal location for a case study due to its geographical site and situation. Virginia Beach is a city set within the Hampton Roads region, which is a major metropolitan area with a wide variety of land uses and waterway obstacles that will necessitate careful documentation for modeling.

\section{Section 3: Research Questions}

The primary focus of this project is the question "What geographic information is needed, and how may it be configured to determine whether nursing home patients are safe during a hurricane event?" To fully answer this primary question, several sub questions have to be investigated. Which nursing homes have a current emergency action plan for the facility? Which nursing homes will evacuate under what type of hurricane conditions? Do they have the means of transportation to evacuate? Where will they evacuate to? If evacuation is not seen to be an option for a particular nursing home under the action plan, there are more questions to be addressed; such as whether sheltering in place is a safe option. Do the nursing homes have doctors on the premises? Are emergency power generation, food, and water supplies available, and for how long? And finally, will the nursing homes be safe from the recently modeled storm surge predictions? 
To answer these questions, a basic understanding of the possible effects of hurricanes in the study area is needed, along with an accounting of the nursing home plans, details of federal and state codes, and identification of the agencies designated to assist in the event of an emergency. Storm surge data used in this research is based on hurricane category. To classify hurricanes and to assist in making predictions of damage, the National Oceanic and Atmospheric Administration [NOAA] hurricane forecasters use a five category disaster-potential scale, commonly known as a Saffir-Simpson Hurricane Scale, Table 1. Category four hurricanes or above are considered to be catastrophic to Virginia Beach due to its low elevation; categories three and four will be discussed and modeled in the course of this research.

Table 1: Saffir-Simpson Scale

\begin{tabular}{|l|l|l|l|l|}
\hline \multicolumn{5}{|c|}{ SAFFIR-SIMPSON HURRICANE SCALE } \\
\hline Category & Winds (mph) & Storm Surge & Damage & Examples \\
\hline 1 & $74-95$ & $4-5$ feet & Minimal & Danny-1997 (AL) \\
\hline 2 & $96-110$ & $6-8$ feet & Moderate & Georges-1998 (FL) \\
\hline 3 & $111-130$ & $9-12$ feet & Extensive & Fran-1996 (NC) \\
\hline 4 & $131-155$ & $13-18$ feet & Extreme & Andrew-1992 (FL) \\
\hline 5 & $>155$ & $>18$ feet & Catastrophic & Camille-1969 (MS) \\
\hline
\end{tabular}

(Simpson, R.H. \& Riehl, H., 1981)

The damage from these hurricanes can be quite extensive. Many communities, including nursing homes, place their confidence in planning against such a storm because the occurrence of one tends to be quite rare. The vulnerability of each community depends on the location. Typically only ten storms a year are classified as tropical storms, and out of those, only about six mature into hurricanes (Definition of a Hurricane, 2007). On average, two of these hurricanes will make landfall somewhere on the eastern seaboard of the United States, between Texas and Maine, causing hundreds of millions of 
dollars in property damage and potentially causing large numbers of casualties

(O’Handley, 2007).

Uncertainties in hurricane motion and tracking create a difficult task for the Emergency Services network to aid and protect the population. Questions such as when and where to evacuate areas become paramount in both the planning and action stages of response to hurricanes. Even with contemporary technology, it is still difficult to predict the movement of a hurricane onto land (American Geophysical Union, 2006).

Virginia Beach is unusual in that hurricanes have affected the area in approaches from several directions. Hurricanes have been known to track from the Gulf of Mexico, across many states, striking the area from the west. Some have blown in directly from the Atlantic Ocean westward, while the majority of storms have tracked across North Carolina from the south causing a complexity for evacuation planning in and around Hampton Roads. To better understand the complexities of hurricane tracks around the shorelines of Virginia, Figure 3 illustrates hurricane tracks from 1980-2005.

\section{Figure 3: Hurricane Tracking 1980-2005}

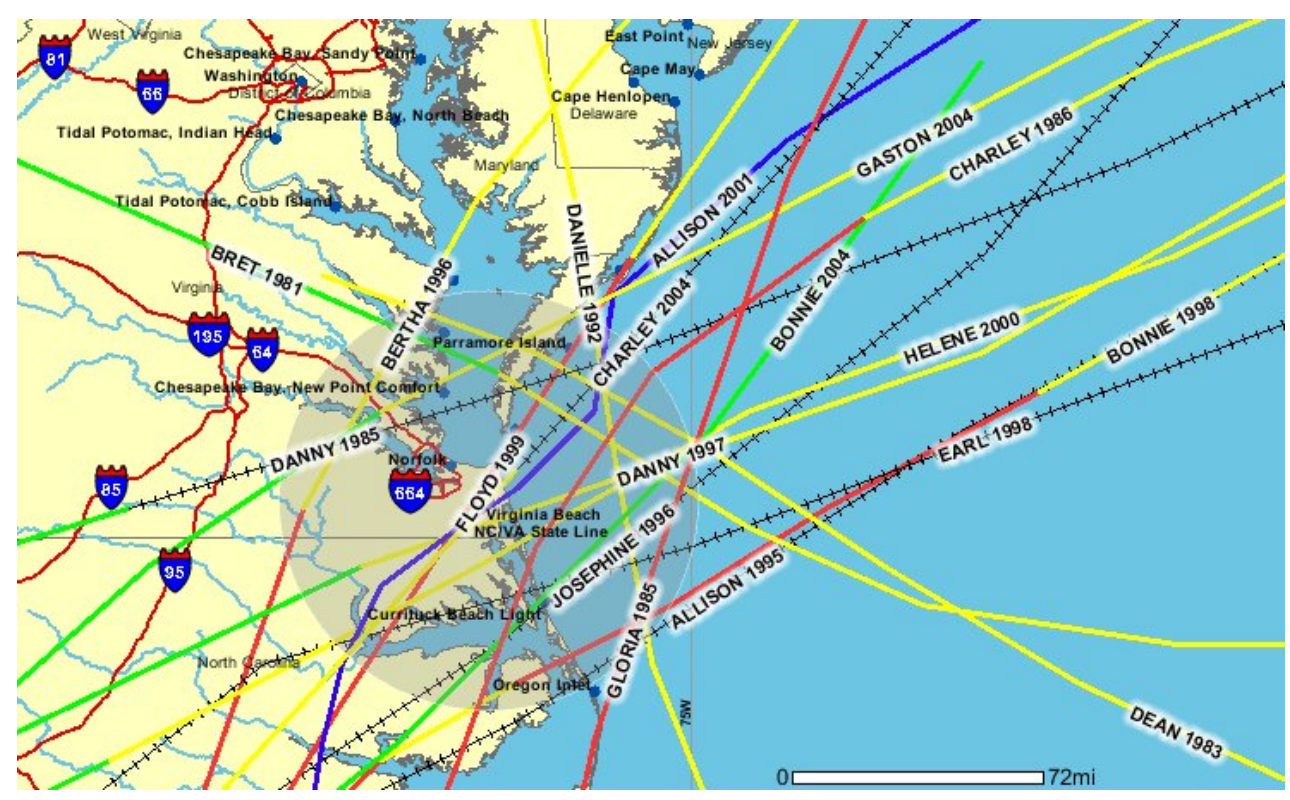

(Source: http://maps.csc.noaa.gov/hurricanes, acquired May 12, 2007) 
Another major question to be addressed is the decision to evacuate. Information gathered through radar systems, satellites, and aerial reconnaissance assist in determining times and safe passage routes from the area being evacuated, and in making the final decision to evacuate, if at all. Evacuations are costly to the population as well as to the government entities involved. The cost of civilian evacuations is usually estimated at approximately \$1M per square mile of area evacuated (Whitehead 2003). The availability and accuracy of forecasts and warning systems are critical to timely evacuation orders for nursing homes and the population in general.

According to federal regulations and the Medicare Conditions of Participation, certified facilities such as nursing homes are required to have "detailed written plans and procedures to meet all potential emergencies and disasters" (Office of Inspector General, 2006, p 2). Although a plan may be required, Hurricanes Katrina in 2005 revealed many failures, raising the question of whether or not homes in Virginia Beach are safe from making the same type of mistakes. A survey of nursing home emergency management plans will address this issue. The primary goal of this research is to tie the responses to these questions together and creating a product useful to the nursing home community, as well as emergency service offices.

\section{Section 4: Methods}

The location of the resources needed to complete the research in Virginia Beach, Virginia necessitated three months of onsite field work. Residence in the study area allowed convenient access to points of contact, development of a contacts network, and to the required data. The first step was to identify the spatial data layers needed for the

database (Table 2). Having identified the basic data requirements, digital copies of these 
layers were acquired from the offices of the American Red Cross, Virginia Department of Transportation (VDOT), Virginia Beach Emergency Management Office, and the Virginia Beach's GIS data center. Each layer was available as, or converted to, a standard ESRI shapefile and associated attribute tables.

Table 2: GIS Data Layers

\begin{tabular}{|l|l|}
\hline Layer & Source \\
\hline Road Network & Virginia Department of Transportation \\
\hline $\begin{array}{l}\text { Digital Elevation (Spot } \\
\text { Heights/ Contours) }\end{array}$ & GIS Center, Virginia Beach \\
\hline Medical Care Centers & GIS Center, Virginia Beach \\
\hline Shelters & American Red Cross, Norfolk, Va \\
\hline Storm Surge & Emergency Management Office, Virginia Beach \\
\hline
\end{tabular}

Georeferencing for the database was established from the 2007 storm surge data created by the Army Corps of Engineers, Norfolk District. This polygon feature, vector digital data had elevation attributes in feet, referenced to the National American Vertical Datum of 1988 (NAVD) (Hamor 2007). The Corps model represented storm surge heights projected upon the still waters of the Atlantic Ocean and Chesapeake Bay during high tide with a $+/-20 \%$ accuracy; this projection does not include wave action or rainfall amounts (Hamor 2007). Storm surge also can affect rivers and inland lakes, potentially increasing the area that must be evacuated (FEMA 2006). To construct the model, the Army Corps of Engineers used contours and spot elevations generated from aerial photography flown in March 2004 by the city of Virginia Beach in a joint effort between the Army Corps, FEMA, Virginia Department of Emergency Management, and local governments (Hamor 2007). The data used the following georeferencing parameters:

Source Scale 1:6,000

Direct Spatial Reference Method: Vector Map Projection: Lambert Conformal Conic Planer Distance Units: Surveyed feet Horizontal Datum Name: D North American 1983 HARN 
Ellipsoid Name: Geodetic Reference System 80

Attribute Label: FID

Attribute Data Source: ESRI

These georeferencing parameters and the Lambert Conformal Conic projection were adopted for the geodatabase and all other data layers and recorded as spatial metadata.

Interviews were conducted at the offices of the American Red Cross Norfolk District, the Emergency Management Office, and the Emergency Operations Center for Virginia Beach. All interviews were conducted face-to-face, reducing the opportunity for miscommunication or misunderstandings. Questions were in an open format and centered on the perceived data needs of these organizations with respect to nursing homes. When conducting these interviews, I focused my questions on how each agency could best assist the nursing home community during hurricane evacuations, what information is required, and how each office played a role ensuring patient safety.

While visiting the American Red Cross, it was imperative to get the locational and attribute data for the emergency shelters in Virginia Beach, since this office provided a list of approved shelters to the Virginia Beach Emergency Management Services [EMS] office on a yearly basis. These shelters include churches and school buildings in Virginia Beach or nearby communities (Bureau of Emergency Services 1995).

The next step was to visit the Emergency Operations Center for Virginia Beach. This visit gave my research validity since the center had not yet incorporated a GIS suite for the city of Virginia Beach, but instead used an outdated software package passed on to them from the State EOC. HURREVAC, the program used, was a collection of single layered maps tracking incidents along the road network, but was limited in regard to 
other uses. Although Virginia Beach is the Hampton Roads Coordinator, reporting directly to the state, they lacked up-to-date data collection and analysis methods.

A VDOT road network and digital elevation data in the form of spot heights and contours was collected from the Virginia Beach GIS Center using the same scale and projection as the other data collected. A digital layer was also acquired that included locational and descriptive data on every type of medical facility in the area. While useful, this layer took many hours of manipulation to render it useful for the database. This manipulation entailed expunging all data with the exception of the 13 nursing homes and changing the source projection to the database's standard.

This data collection step was critical in further developing the GIS model. Since emergency situations vary from city to city and county to county, every nursing home must develop an emergency action plan unique to its site. An emergency plan should be simple and to the point, prescribing actions of staff in a specific and easy to understand way (Virginia Department of Health 2007). These plans should lay out the procedures necessary for defending in place and evacuation during the event of an approaching hurricane. Although evacuation may be impractical in many cases, except as a last resort, a plan must be developed in case that last resort becomes necessary. Each emergency plan should be followed up with training and educating to minimize mistakes during an actual event. Since the research on evacuation planning focused on Virginia Beach nursing homes, the data collected was the population of nursing facilities (patients and staff), proposed evacuation decisions, proposed evacuation sites, generator status, and transportation availability. These data were essential to model scenarios and plans for the Virginia Beach Emergency Management Office and Public Health Department. 
Prior to visiting the individual sites, support and approval was gained from the Virginia Beach Department of Public Health and the Office of Emergency Management. A list of nursing homes was compiled for site visits in the city of Virginia Beach. This list included:

- Sentara Nursing Center Windermere

- Berger-Goodrich Home at Beth Sholom

- Our Lady of Perpetual Help

- Heritage Hall

- Oakwood Nursing Home and Rehab

- Beacon Shores Rehabilitation Center

- River Point Rehab and health Care

- Sentara Nursing Center Virginia Beach

- Bay Pointe Medical and Rehabilitation

- Bayside Health Care Center

- Virginia Beach health Care and Rehabilitation

- Westminster-Canterbury

- Seaside Health Center.

Each nursing home was visited to review its evacuation plan and to obtain an overview and details of their intentions during an evacuation. Most directors and administrators were very forthcoming and provided their emergency plan and discussed it at length. Nevertheless, a few agreed to meet with me, but tended to be very guarded while referencing their emergency action plans; with one director refusing to meet with me outright. That facility will be noted in this study by locational data only.

Once this data was collected, ARCGISTM (Version 9.1) was used to create the desired maps. The primary GIS layers used in creating the maps were the elevation, storm surge, road networks, shelters, and the nursing homes. Each map was designed to convey the danger of the predicted storm surge to nursing homes in Virginia Beach and relevant nearby shelters. The road network depicting possible road closures is represented in addition to the predicted access to major evacuation or supply routes. The 
study area was large, so in order to show finer details for each facility, the area map was broken into a series of larger scale maps. To help the user shift from one map to another, a bookmark feature was incorporated. A bookmark allows the user to view each detailed, large scale map by a single click and easily return to the home page. Another feature that was incorporated is access to nursing facility information. Double clicking the facility symbol activates a hyperlink to a word document, allowing the user full access to each nursing home's emergency plan of action. The specific information accessed through this hyperlink is the site's name and address; the administrator's name and phone numbers; current evacuation plan under each hurricane condition; the number of patients; the number of patients requiring medevacs; the number of staff; electrical generator information; and other major concerns as appropriate. Legends, scales, and north arrows were added for ease of referencing, with the scale and arrow set outside the map for a clearer interpretation.

\section{Section 5: Results and Findings}

To help nursing homes develop their individualized hurricane plans and assist the Emergency Operations Center in its evaluation of evacuate plans, it is important to focus more closely on individual nursing homes. This chapter will examine emergency plans of nursing homes during category three and category four hurricane surges. 
Figure 4 displays category three storm surge data and locational data for both nursing homes and shelters. Most of the nursing homes to the west and on the high

\section{Figure 4: Homes and Shelters during Category Three Storm Surge}

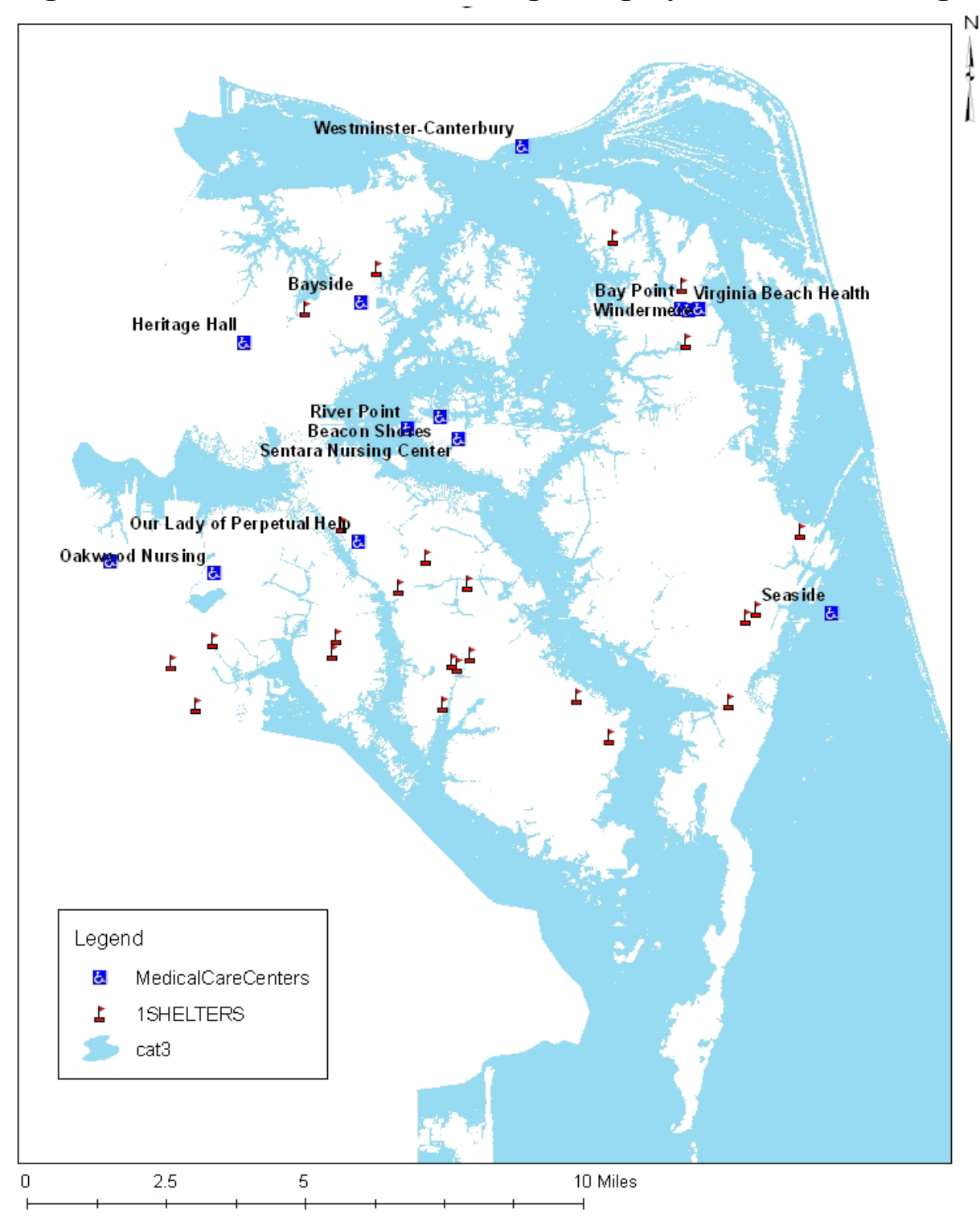

ground near the beach are relatively safe under these conditions. Shelters have been extremely well placed as none of them are inundated by the category three surge. Although shelters are not currently an option for nursing home evacuations, it is my intention to show shelters are a plausible option. Two examples of this are the 
Westminster and Seaside nursing homes, both forecast to be in a flood zone, and their relative location to the safety of available shelters. Shelters in this area tend to be schools. For Westminster, the shelter two miles to the southeast is Cox High School, and for Seaside, the shelter one mile to the west is Corporate Landing Middle School. This information is all readily available and retrievable from the GIS database.

Figure 5, illustrates the nursing homes that will be possibly inundated by category

Figure 5: Possible Categorv Three Flooding for Nursing Homes

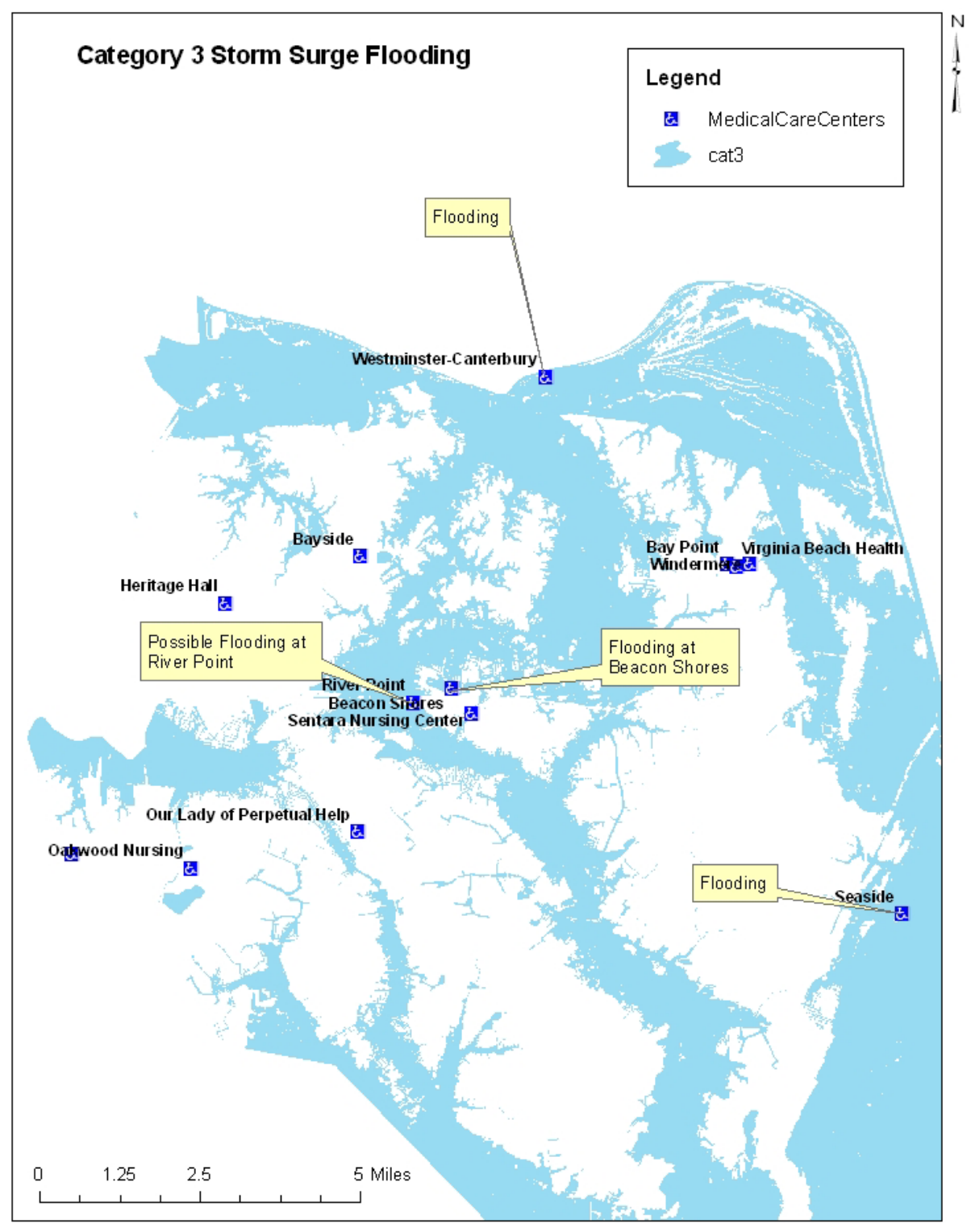


three storm surge flooding. These homes intend to remain in place if a category three hurricane is predicted to strike this area. Seaside nursing home is predicted to be completely flooded and with the emergency generators located on the ground level, they will experience a complete loss of power. Under these circumstances, attention will be needed in the immediate aftermath of the storm to aid survivors. Westminster will also be flooded but the portable generator is located on the third floor, the residents will be able to evacuate vertically from flooding, but will still have to deal with potential risk from the high winds associated with the storm. Beacon Shores and River Point nursing homes will start to experience flooding during this category of hurricane. Generators located on the ground level means that loss of power will certainly be an issue.

A category four hurricane is catastrophic event. Maps being modeled in this project reflect storm surge data alone and in do not reflect attributes of sustained winds above $130 \mathrm{mph}$, flying debris, tornados, or fallen trees. In Figure 6, half the nursing homes are under storm surge flooding predictions. Over $90 \%$ of the shelters are no longer available for the population of Virginia Beach. Nursing homes such as Beacon Shores, Sentara Nursing, River Point, and Our Lady of Perpetual Help nursing home emergency plans call for sheltering in place and will now be a major concern for the emergency management office. 
Figure 6: Category Four Storm Surge

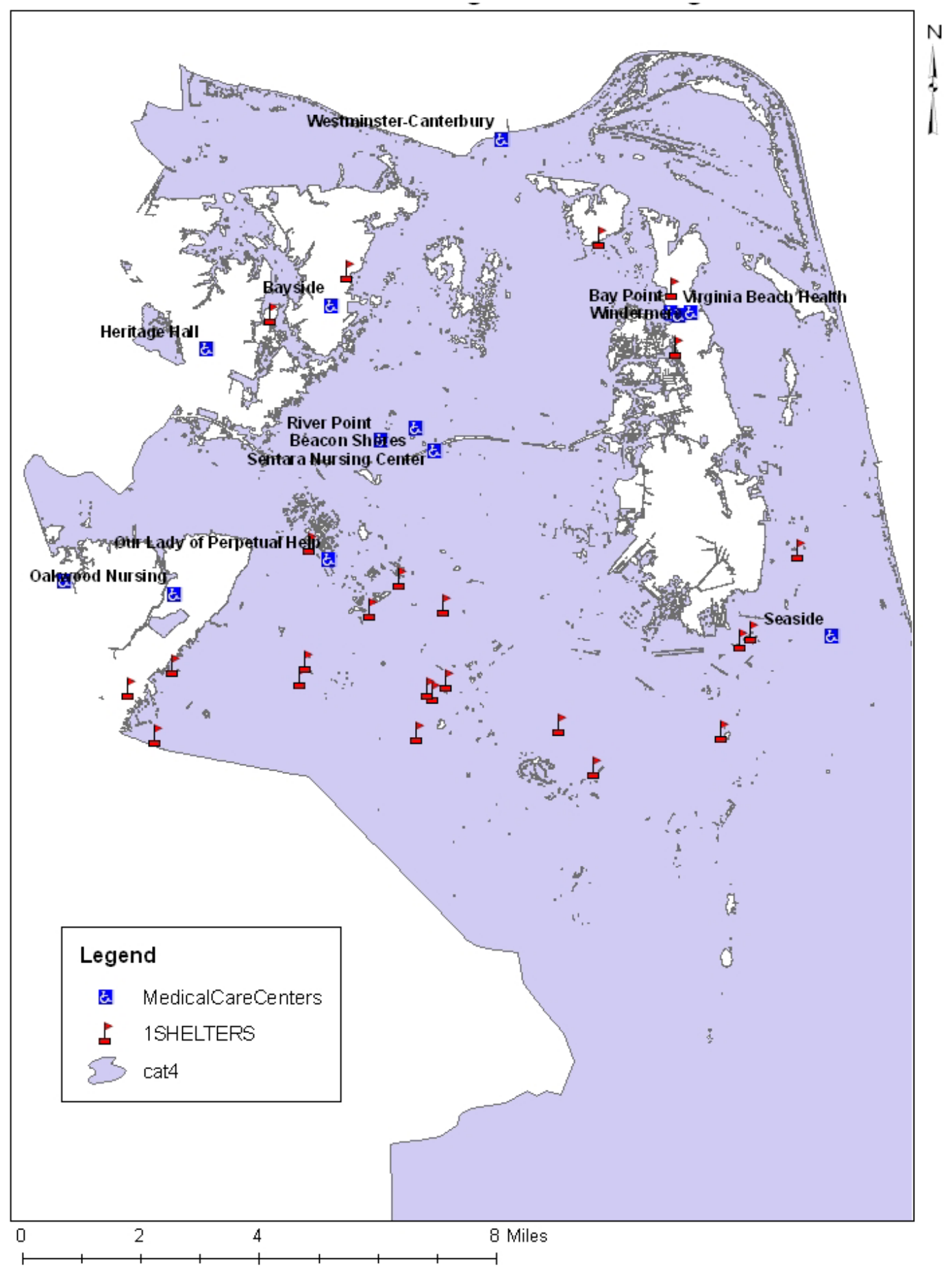

To access each nursing home's plan, larger scale maps are needed. The first set of maps I will model is for nursing homes on higher ground, miles inland form the beach (Figures 
7/8). Although they have access to shelters in their area, they will never be used under category three conditions as modeled. Each has a complete team of doctors and nursing staff, access to all medical equipment, medicines, records, and their own generator, defending in place at this storm classification is more than justified.

\section{Figure 7: Berger-Goodrich/Oakwood Nursing Homes, Category Three Surge}

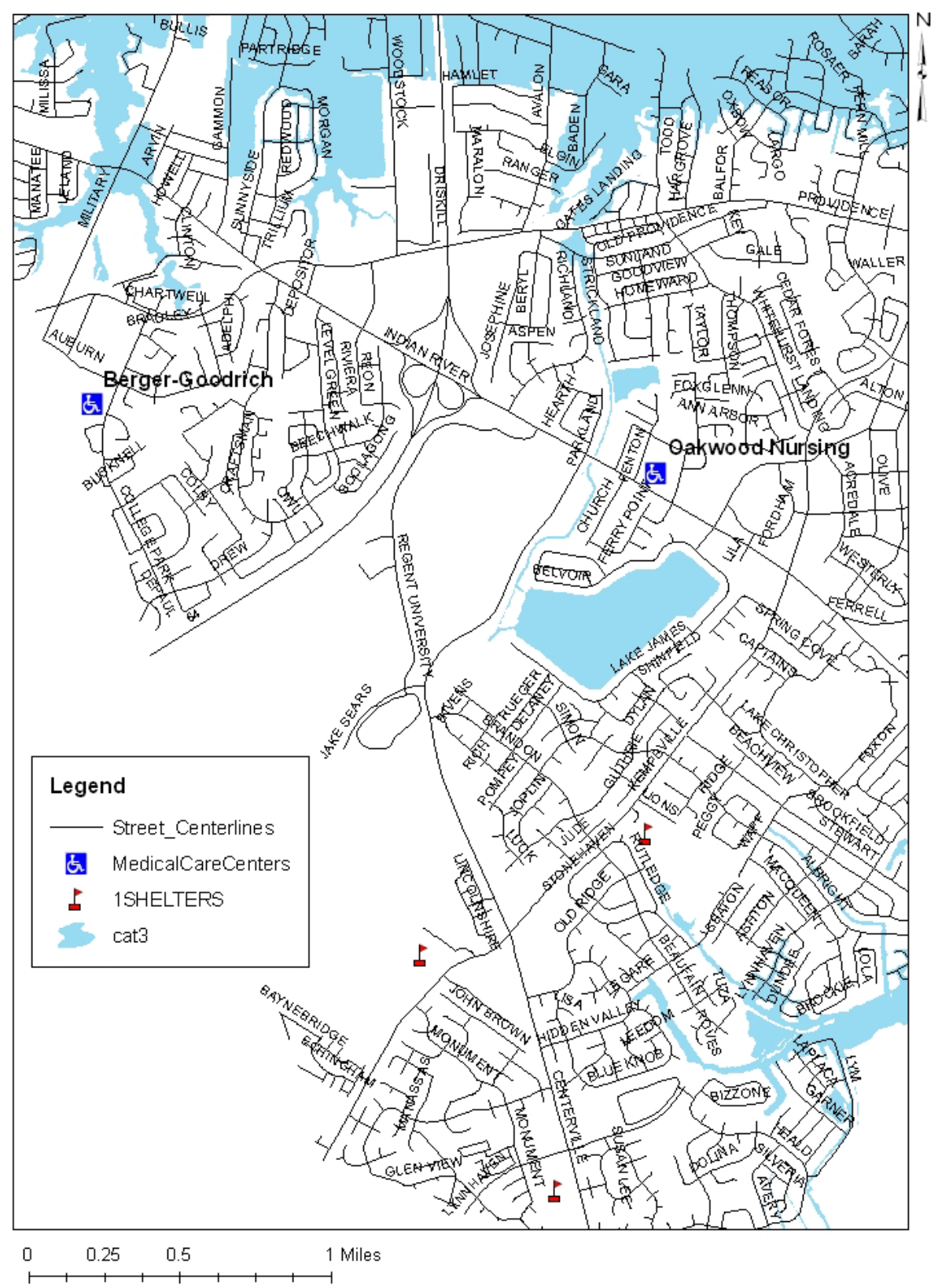


These homes are on higher ground and further inland than most of the facilities in the area. With all the necessities available to them, the decision to defend in place is a

Figure 8: Heritage Hall/Bayside Nursing Homes, Category Three Surge

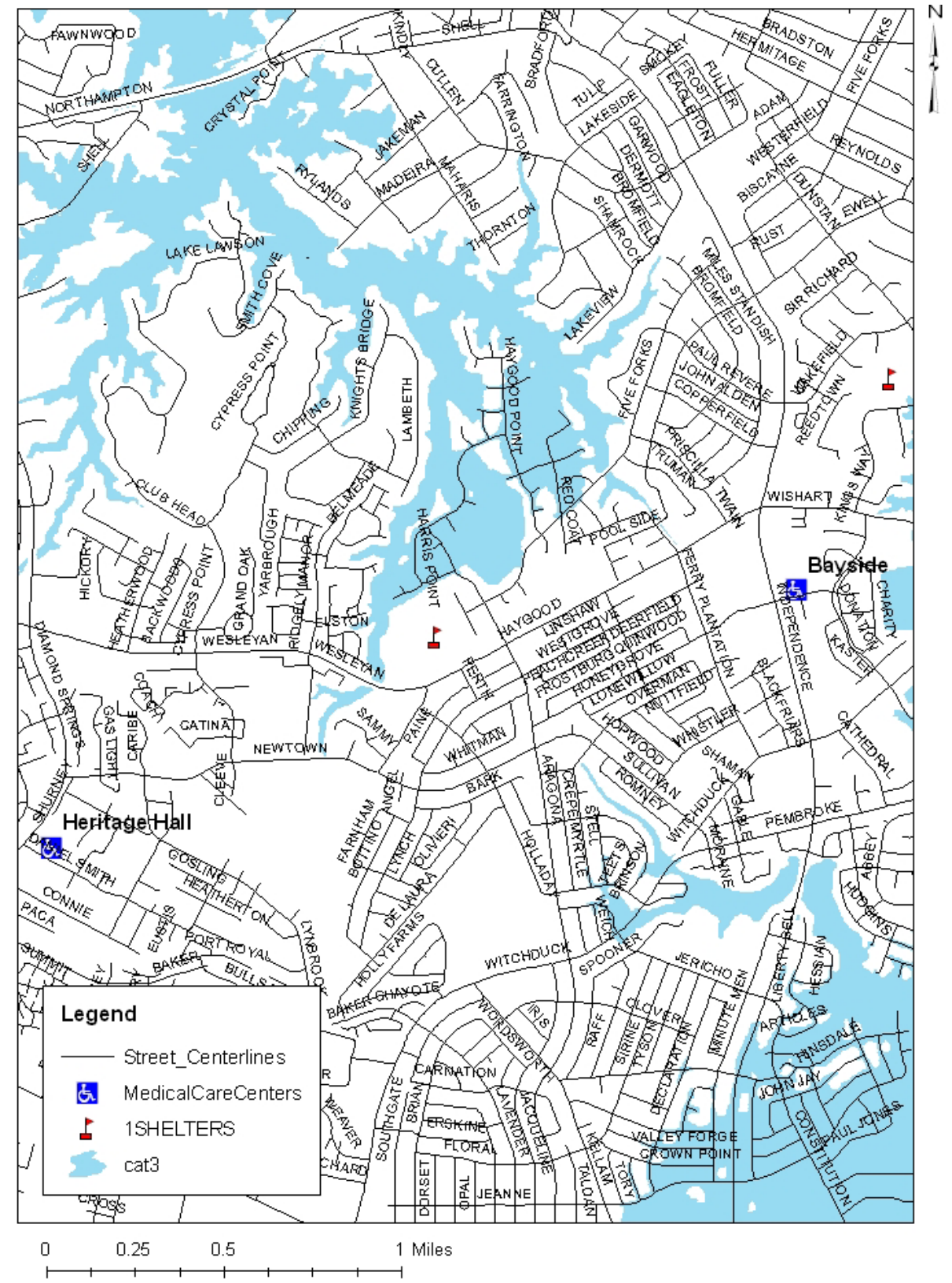

very reasonable plan. The same findings hold true for Bay Point, Va. Beach,

Windermere, and the Lady of Perpetual Help nursing homes; all on higher ground. 
Turning our attention to nursing homes that are predicted to have storm surge problems during a category three hurricane, Figure 9 illustrates River Point, Beacon Shores and Sentara nursing homes during a category three predicted storm surge.

\section{Figure 9: River Point/Beacon Shores/Sentara Nursing Homes, Category Three Surge}

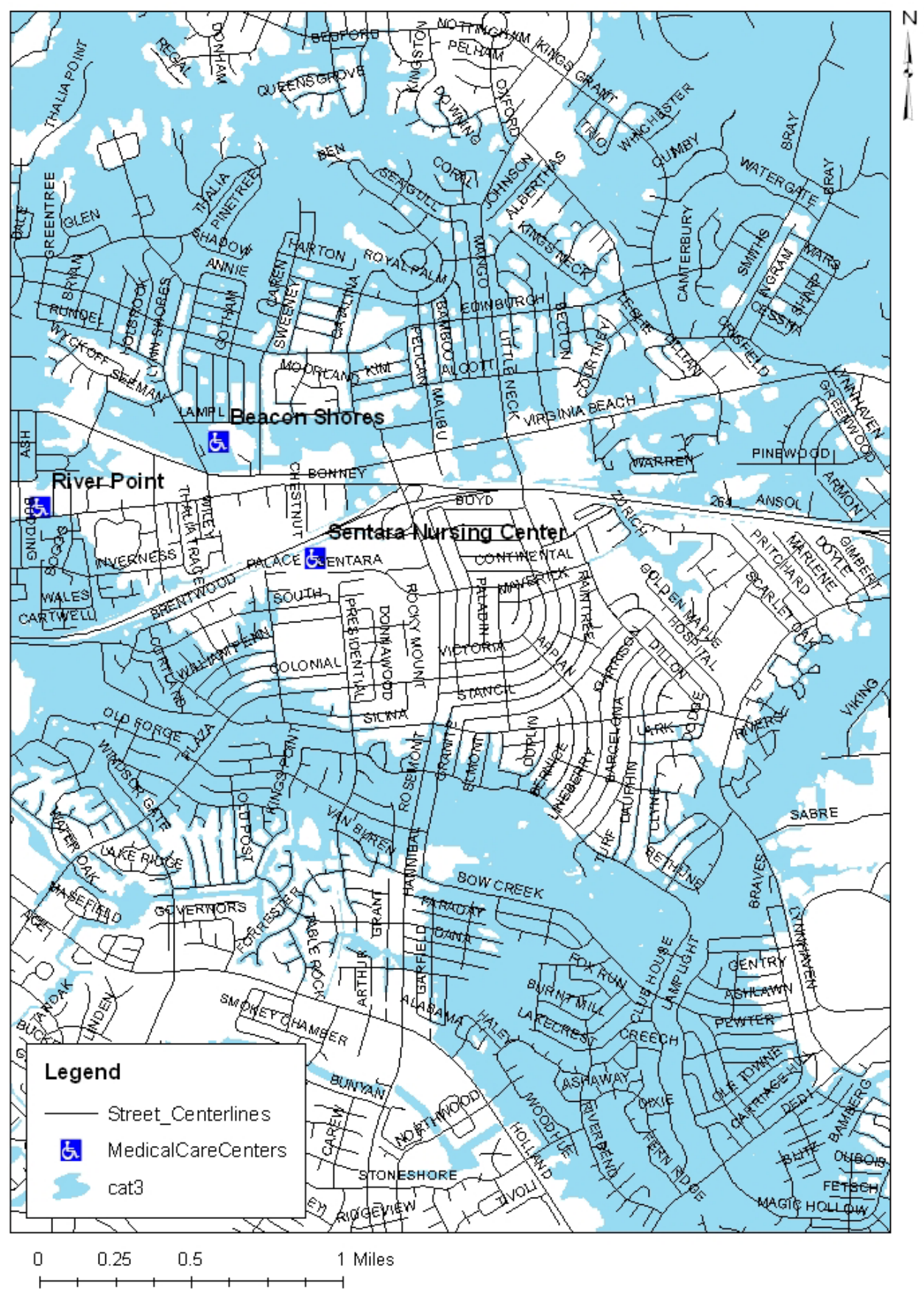


All three nursing homes are surrounded by water and are on an existing hurricane made island. Worst case scenarios predicted for Beacon Shores shows them to be flooded during this storm surge, with River Point right on the edge of the same demise.

Westminster nursing home, in Figure 10, will be enduring flooding during this category of Hurricane. Their current plan is to defend in place by evacuating the first two floors and fleeing vertically. They have backed up this plan by installing a $3^{\text {rd }}$ and portable generator on the $3^{\text {rd }}$ floor of the nursing home. There is a shelter that is three miles southeast of the facility that could be used as a last resort. 
Figure 10: Westminster-Canterbury Nursing Homes, Category Three Surge

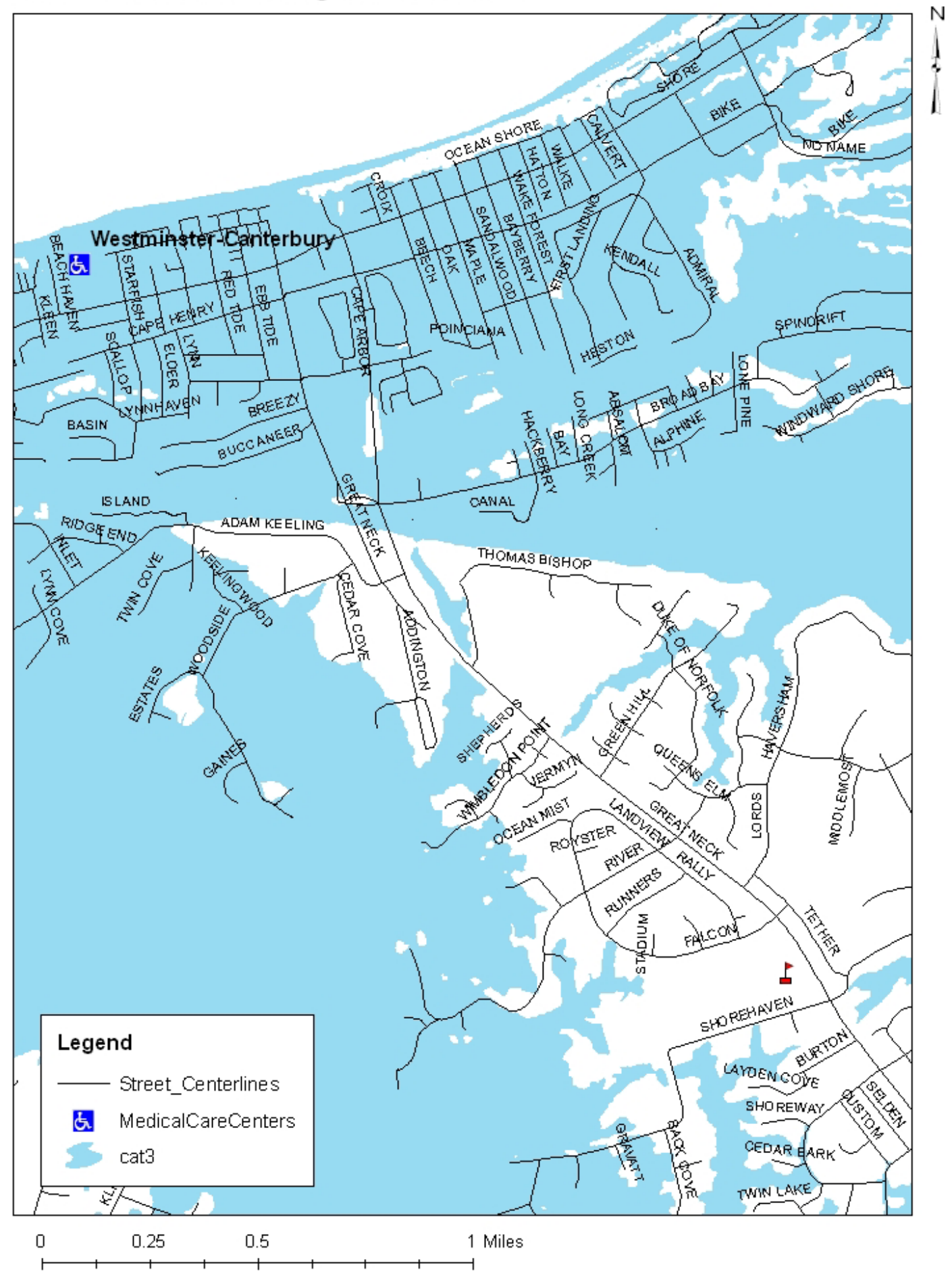


Seaside Nursing home is also defending in place during a category three hurricane. With their generator on the ground level, loss of power will be inevitable. As seen in Figure 11, once the storm hits, the only evacuation possibility will be to nearby shelters, two miles west.

\section{Figure 11: Seaside Nursing Homes, Category Three Surge}

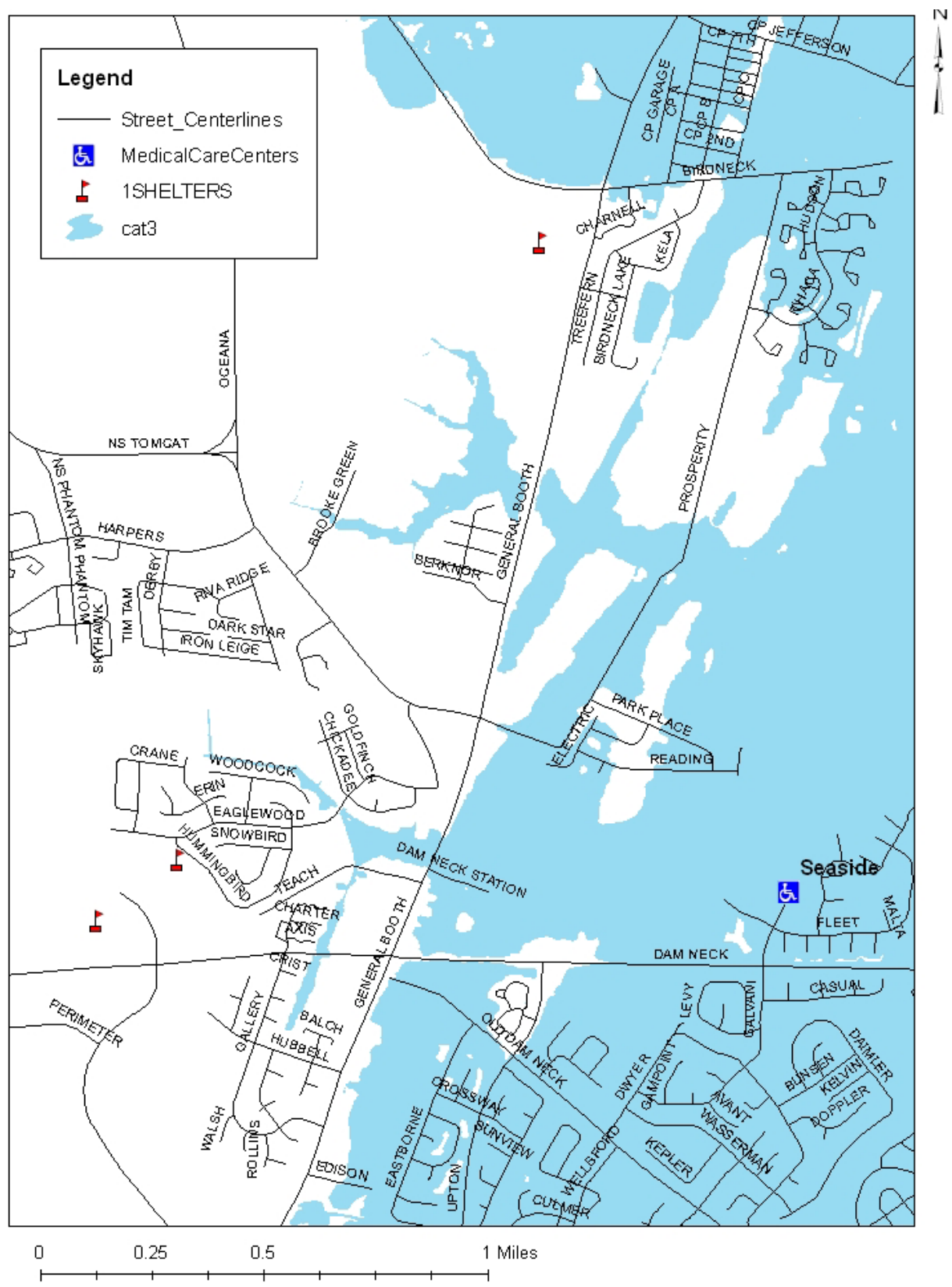


Moving into category four model assessments, most nursing homes have conveyed a concern and a need to evacuate the area for both category four and category five hurricanes, but the transportation and designated evacuation site have not been established. (The entire area is predicted to be underwater for category 5) In Figures 12 through 14 are nursing homes inland and on higher ground.

Figure 12: Berger-Goodrich/Oakwood Nursing Homes, Category Four Surge

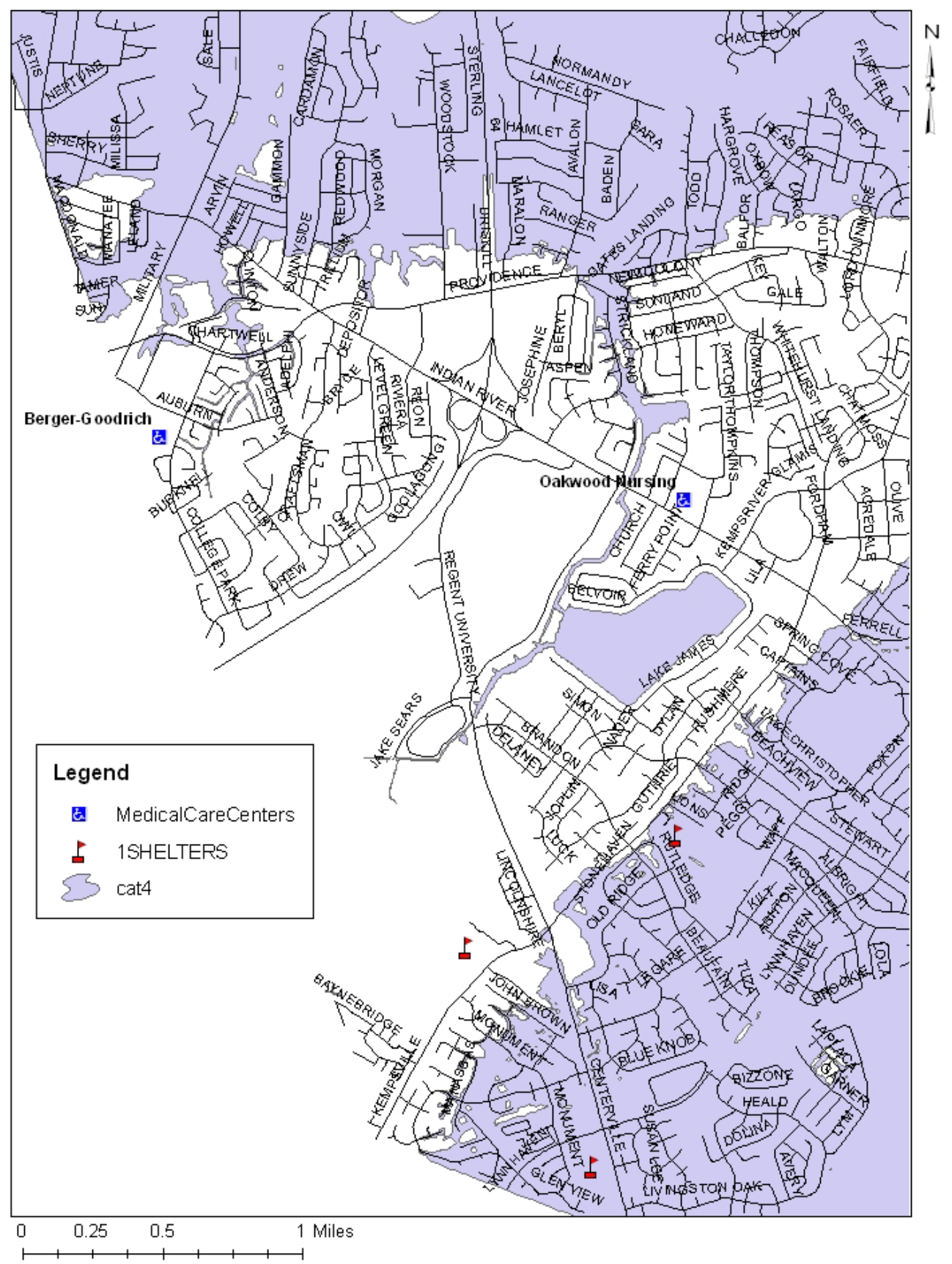


Figure 13: Heritage Hall/Bayside Nursing Homes, Category Four Surge

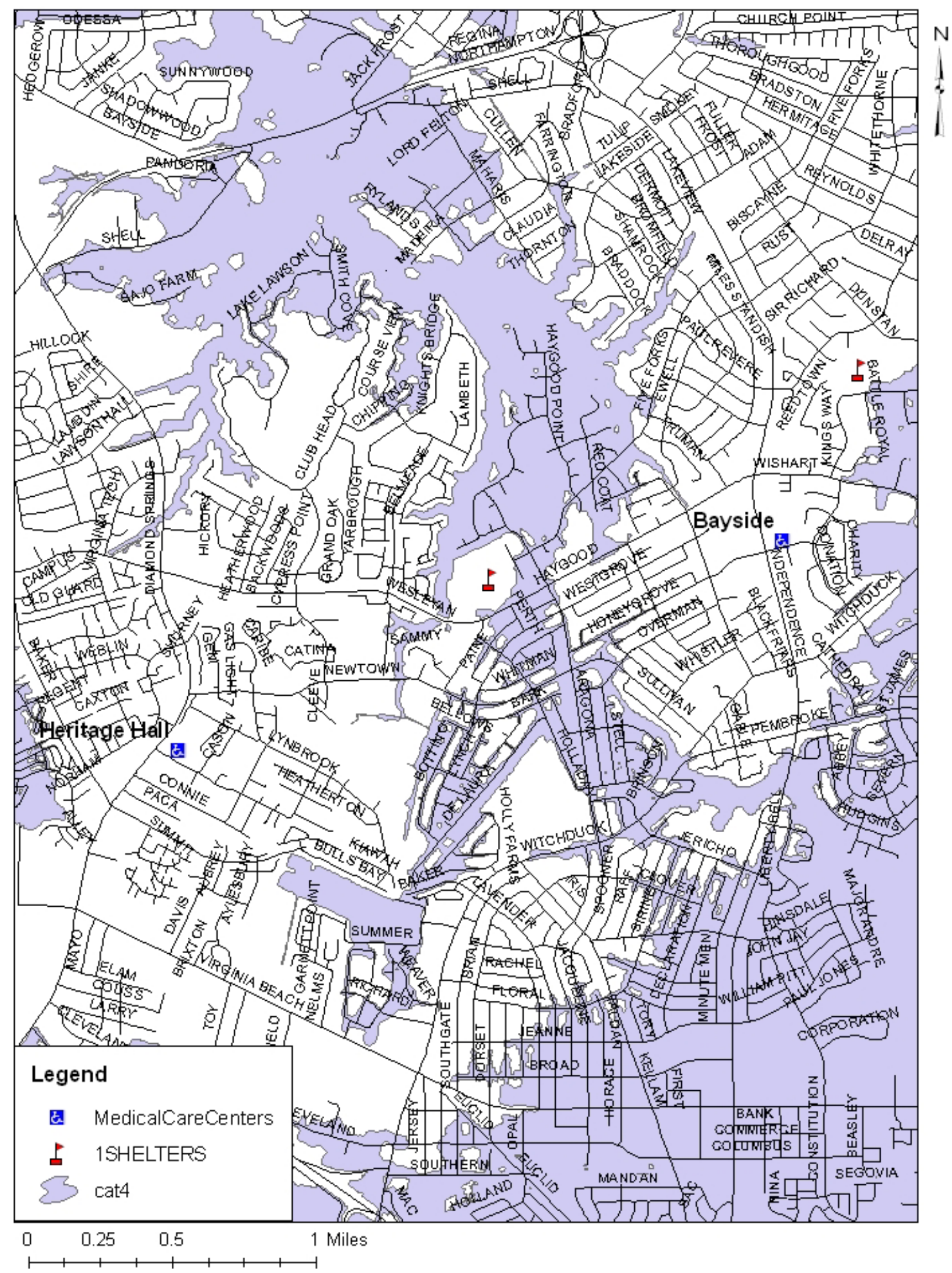


Figure 14: Bay Point/Virginia Beach Health/Windermere Nursing Homes, Category Four Surge

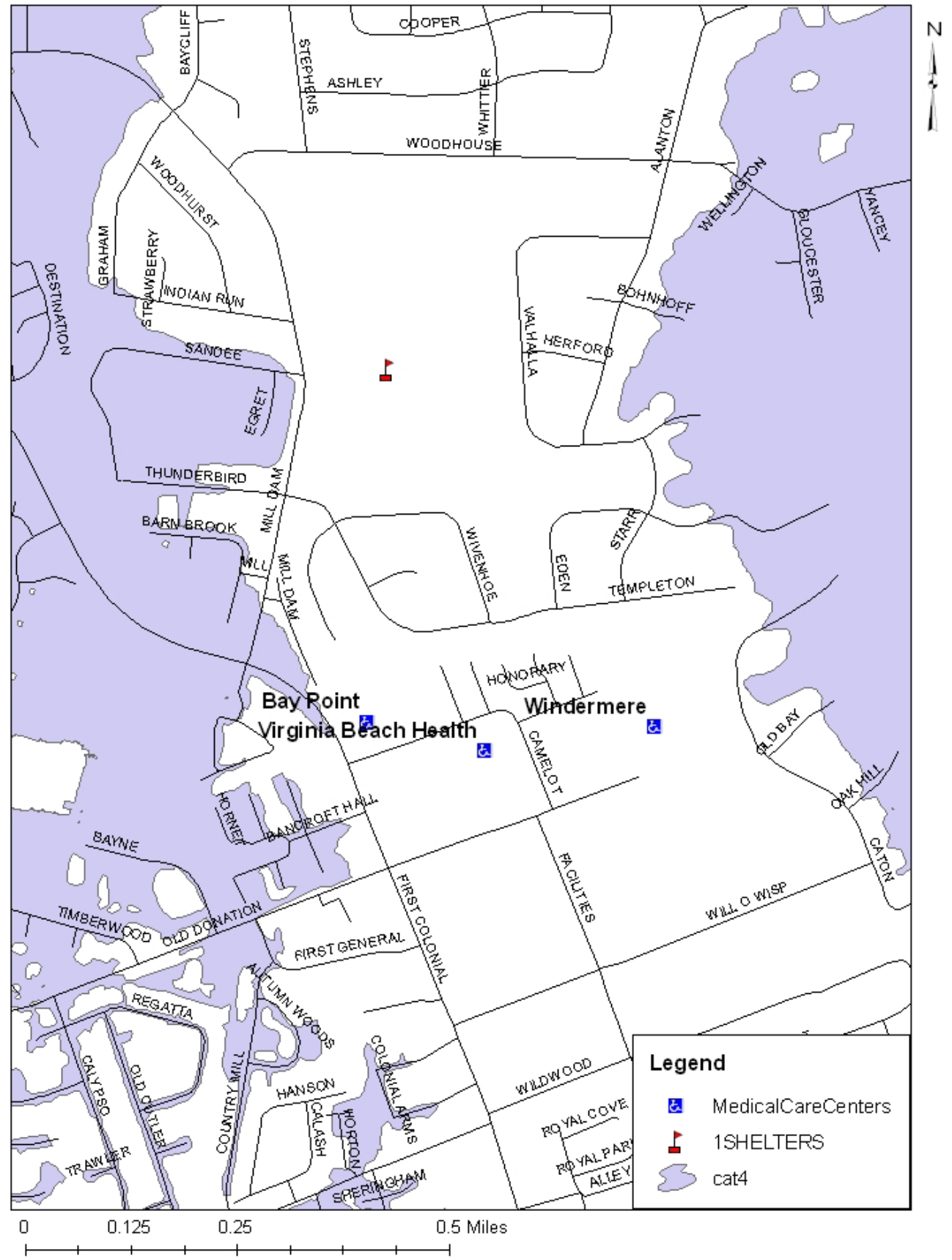

Berger-Goodrich, Oakwood, and Heritage Hall all plan on defending in place.

Although located on higher ground, the reason for defending in place is the lack of a destination facility to house their patients. Bay Point and Windermere both have expressed a desire to evacuate under these conditions but either lack the transportation 
option or have no destination for the patients to go to. Bayside and Virginia Beach Health have sister facilities to evacuate to prior to a category four hurricane but both are still lacking the transportation means.

All other facilities during a category four storm surge are predicted by the office of the Army Corp of engineers to be in a flood zone (Hamor, 2007). Most plan to evacuate, but facilities such as River Point, Sentara Nursing, Beacon Shores, and Our Lady of Perpetual Help will try to defend in place amidst the storm surge predictions due to the lack of options.

As the models clearly demonstrate, there are some valid concerns for the readiness conditions of some of the nursing home facilities in the city of Virginia Beach. In the event of a category three hurricane, approximately one-third of the homes will be in need of emergency assistance, which they will only receive in the aftermath of the storm. For a category four hurricane, the models demonstrate that number will increase to nearly one half. The models also show that the areas of the most concern are the beach front properties, the River Point area, and the Indian River area (Our Lady of Perpetual Help). Another area of concern is the Bay Point area. Although the three nursing homes in that vicinity all are depicted as being safe from the predicted storm flood zone, they will be isolated on a storm made island with a predictable loss of power and will have to rely on their generators.

\section{Chapter 6: Conclusions}

The two goals of the geodatabase design and implementation were both met. First, the creation of a visualization of the situation of each nursing home to be taken into consideration while revising their emergency plans, and second, a useful tool was created 
for the Emergency Operations Center and Department of Public Health in Virginia Beach to utilize for future reference.

A lack of communication was found between the various local agencies and must be further explored and implemented throughout emergency planning. Nursing homes should gather information, for example about transportation and shelters that might be of assistance to their needs during a hurricane evacuation or their decision to defend in place. Communication channels should be established by the nursing homes with organizations like the Department of Public Health, Emergency Management Office, Red Cross, VDOT, Emergency Operations Center, and medical facilities outside the local flood zones. In addition, training should be conducted at every facility with key players attending all relevant conferences that offer guidance in the hurricane-related preparedness field. Nursing home emergency plans need to be updated to reflect the most recent storm surge data that clearly puts some of the establishments at risk; according to the models provided here. In the opinion of the author, a few of the nursing homes studied will not be able to defend in place during a category three hurricane and need to adjust their plan to evacuate accordingly. This also applies to nursing homes that fall into the storm surge zones of a category four hurricane and plan to defend in place under such conditions.

As the enforcement of nursing home emergency action plans is relatively recent, many of the nursing homes in Virginia Beach either do not have a plan, or have a plan in progress and are currently working on it. The Emergency Management Office has recently delegated the task of verifying these plans to the Department of Public Health and in the past two months, verification of these plans has been a top priority. While working hand in hand with Ms. Erin Sutton (Director of Virginia Beach Public Health 
Office), interviews were conducted with over $90 \%$ of the facilities in the area; collecting their plans, talking to directors, and developing a scenario of what each facility was planning for each category of hurricane. One unanimous decision was reached by all; every nursing home plans to shelter in place against category 1 , category 2 , or category 3 hurricanes. Decisions varied from facility to facility on categories 4 and 5; these decisions were evaluated in the previous section.

The local Red Cross office made it clear that shelters were not approved for hurricane refuge and were not suitable for nursing homes to use without considerable assistance. Upon reviewing the models, a majority of shelters are relatively safe from storm surge damage and might be useful with "some" modifications to be of use to the nursing homes under extreme conditions. As the conditions exist today, places like the River Point area may be surrounded by water in a category three hurricane and utilizing whatever shelter is available may be essential, regardless of the condition or approval from the Red Cross. Further research should be done through the Army Corp of Engineers, FEMA, and the Red Cross to access the feasibility of such an undertaking or discuss other plausible options for the nursing homes in the area; as well as the population in general.

Although emergency plans are required by law to be complete, they were always in a state of flux. Each plan, unique to every facility, was constantly being changed and updated, classifying them as work in progress. This uncertainty may be attributed to the constant stream of new information, such as hurricane surge data, broken transportation contracts, changes in staffing, policy shifts, or a misinterpretation of exactly what was required of them in the first place. However, this reflects important adaptations to new information and conditions. 
In discussion with each of these homes, transportation is the number one priority for planning the evacuation of nursing homes in Virginia Beach. With just two exceptions, nursing homes have been unable to secure transportation for their patients in advance of a disaster. Some of the establishments have a dedicated vehicle or two, but are not prepared to evacuate the entire population of their home. Most homes have approached the city's local transportation office (Hampton Roads Transit) in trying to secure city buses and have been refused assistance. Some have pushed forward in their search and found local businesses (e.g. Fun Tour Buses) to commit to a contractual agreement with their home, but have concerns on its reliability and the number of patients they will actually be able to evacuate. Those nursing homes that do not have plans in place for transportation will find themselves relying on state and federal help for evacuation. This reliance will be an issue because both federal and state entities are already inundated with other concerns in the community and have a limited supply of transportation options already in place.

The findings of this research will be given to the Virginia Beach Department of Public Health, and subsequently distributed to the local nursing homes, Emergency Management Office, and state and local EOCs. The GIS database itself will be given to the Virginia Beach Department of Public Health and later implemented into the operations of the local EOC, once further research is carried out and modifications are implemented. As with any database, there is always room for growth, maintenance and improvement to the system. I will continue to assist in this incorporation of new technology to ensure a smooth transition over to the local agencies and maintaining and updating database management. 


\section{References Cited:}

American Geophysical Union (2006). Hurricanes and the U.S. Gulf Coast: Science and Sustainable Rebuilding. Retrieved on August 11, 2007 from http://www.agu.org/report/hurricanes/full_report.html

Bureau of Emergency Services. (1995). City of Norfolk shelter management: Student's manual. Norfolk, VA: Government Printing Office.

Definition of a hurricane. Retrieved on July 2, 2007 from http://www.cppj.net/dept/oep/defhur.asp

FEMA (Federal Emergency Management Agency) (2006, July). Sea, Lake, Overland, Surge from Hurricanes. Retrieved on May 17, 2007 from http://www.fema.gov/plan/prevent/nhp/slosh_link.shtm

Hamor, M.L. (2007, April). Army Corp of Engineers, Norfolk District: Virginia Beach Hurricane Evacuation Study.

Laditka, S.B (2006). USC Katrina Crisis. Retrieved June 21, 2007 from http://www.sc.edu/katrinacrisis/laditka.shtml

O’Handley, C. (2007, March). Weathering the Storm: Emergency Planning for People with Special Needs. Your Power, Your Choice Conference conducted at Old Dominion University, Norfolk, Va.

Office of Inspector General (2006, August). Nursing Home Emergency Preparedness and Response during Recent Hurricanes (OEI-06-06-00020) Washington, DC: General Printing Office.

Roberts, M. (2006, September). Nursing Home Owners Sue over Katrina. Retrieved on July 21, 2007 from http://www.redorbit.com/news/display/?id=645761

Terwilliger, J. (2007, March). Weathering the Storm: Emergency Planning for People with Special Needs. Your Power, Your Choice Conference conducted at Old Dominion University, Norfolk, Va.

United States Government Accountability Office (2006, February). Congressional Committee: Disaster Preparedness: Preliminary Observations on the Evacuation of Hospitals and Nursing Homes Due to Hurricanes (GAO-06-443R 2006). Washington, DC: General Printing Office.

Virginia Department of Health (2007, March). Rules and Regulations for the Licensure of Nursing Facilities (12 VAC 5-371-190).

Walker, D. M. (2006, March). Hurricane Katrina: GAO's Preliminary Observations Regarding Preparedness, Response, and Recovery: GAO-06-442T. GAO Reports, 1-50. 
Whitehead, J. C. (2003). One million dollars per mile? The opportunity costs of Hurricane evacuation. Elsevier Ltd. 


\section{ANNEX A - Interviews}

Interview with Mrs. Pam Wakefield conducted on June 5, 2007 from 1:00 pm to 2:30 pm at the American Red Cross Office Norfolk [located 611 West Brambleton Ave., Norfolk, Va.].

Interview with Mrs. Erin Sutton conducted on May 25, 2007 from 9:00 am to 11:00am at the Virginia Beach Department of Public Health Office [located Pembroke Corporate Center III, 4452 Corporation Lane, Virginia Beach, Va.].

Interview with Mr. Mark Marchbank conducted on March 9, 2007 from 11:30 am to $12: 10 \mathrm{pm}$ at Old Dominion University Webb Center, Norfolk, Va. 